\title{
EFFECT OF MICROBIAL TRANSGLUTAMINASE TREATMENT ON SOFT CHEESE PROPERTIES
}

\author{
Waleed A. Mahmood \\ College of Agric. and Forestry \\ Mosul University, Iraq
}

\author{
Nawal H. Sebo \\ College of Agriculture \\ Salahaddin University, Iraq
}

\begin{abstract}
Microbial transglutaminase (MTGase) was isolated from the bacteria Streptoverticillium mobaraense and used to improve the yield and properties of soft cheese manufactured from cow milk by enhancing the cross-linking reaction among milk proteins. The enzyme was applied at different concentrations and at various addition times. Results indicated that the addition of the enzyme before rennet prevented milk coagulation while the simultaneous addition of MTGase and the rennet significantly decreased curd strength and cheese hardness and increased the loss of proteins and fat in the whey. It was found that the most suitable way of adding the enzyme was after coagulation and curd cutting. This treatment enhanced the cross-linking of whey proteins with the curd proteins which was proportional to the concentration of the added enzyme up to 60 enzyme units/liter. The crosslinking reaction was verified by SDS-PAG electrophoresis experiment which showed a high molecular weight band accompanied by a decrease in the density of $\alpha_{\mathrm{s}}$-casein, $\beta$-casein and whey proteins bands. Transglutaminase affected the produced cheese composition noticeably by increasing protein content, total solids and decreasing the protein content of the whey. Sensory evaluation of the obtained product showed that the enzyme treated cheese was superior to the untreated cheese throughout all storage period ( 8 days).
\end{abstract}

\section{INTRODUCTION}

Cheese production is rising sharply and so is whey. Several billion pounds of fluid whey are produced annually as a by-product all around the world. It is not efficiently utilized and more than $80 \%$ of this whey ends up as pollutant. In conventional processes for cheese making, a considerable amount of protein is lost with the whey, as protein is a valuable component of milk and milk products. One of the efforts to reduce cost of cheese production has been to keep the whey proteins from being lost in the manufacturing process. Several methods have been proposed to recover whey proteins. They included the concentration or drying the whey proteins and adding it to the cheese curd, heat or pressure treatment of the milk, and concentration of the milk by ultrafiltration, evaporation or reverse osmosis (Ernstrom et al., 1980; Hinrichs, 2001; Kosikowski, 1977; Lo and Bastian, 1998; O'Reilly et al., 2001). Most of these methods are inefficient due to the lost of whey proteins during curd pressing stage. One of the most attractive methods of recovering whey proteins is the enzymatic treatment of milk or curd with transglutaminase which links whey proteins with curd proteins leading to a noticeable increase in protein and yield of the cheese accompanied by a decrease in whey protein content. This treatment has economical, nutritional and environmental importance.

Part of Ph.D. Dissertation of the second author. Received 30/12/2008 Accepted 25/3/2009 
Transglutaminase (Protein-glutamine : Amine $\gamma$-glutamyl transferase, EC: 2.3.2.13) catalyzes the acyl-transfer reaction between the $\gamma$-carboxamide group of peptide-bound glutamine residues and various primary amines, including the $\varepsilon$ amino group of protein lysine residues. The cross-links introduced by this enzyme change the protein structure and improve its functional properties, like texture, viscosity and water-holding capacity without decomposing the nutritional quality of the lysine residue (Seguro et al., 1996). The enzyme is found in almost all eukaryotic and prokaryotic organisms. It has been approved by food industry to improve quality of many foods such as meat, fish, soy products, yogurt, ice cream and cheese (Zhu et al., 1995; Motoki and Seguro, 1998; Kuraishi et al., 2001).

Several factors may affect the efficiency of transglutaminase in stimulating the cross-linking of whey proteins with the curd proteins such as temperature, $\mathrm{pH}$, concentration of the enzyme, heat pretreatment of the milk, availability of cofactors and the step in cheese manufacture at which the enzyme is added. The present work was aimed to investigate the effect of MTGase concentration and its addition time on the physical and sensory properties of the produced cheese as a function of storage time.

\section{MATERIALS AND METHODS}

Chemicals: N-carbo-benzoxy-L-glycine, L-glutamic acid $\gamma$-monohydroxamate and hydroxylamine were obtained from Sigma Chemical Co. Calf rennet was from Chr. Hansons Laboratories, Copenhagen. All other chemicals were reagent grade.

Bacterial cultures: A lyophilized culture of Streptoverticillium mobaraense (DSM40847) was obtained from Deutsche Sammulung Von-Micro-Organismen Und Zelkulturen $\mathrm{GmbH}$ (DSMZ). The culture was maintained on slants of malt extract agar at $30{ }^{\circ} \mathrm{C}$ for 6 days and stored at $4{ }^{\circ} \mathrm{C}$. The bacteria were transferred from the slants to $100 \mathrm{ml}$ of the propagation medium used by Ando et al. (1989) and contained $0.5 \%$ glucose, $0.2 \%$ peptone, $0.2 \% \mathrm{~K}_{2} \mathrm{HPO}_{4}$ and $0.1 \% \mathrm{MgSO}_{4}$ at $\mathrm{pH} 7$ in $500 \mathrm{ml}$ Erlenmeyer flasks. Propagation was conducted in a shaker incubator at 30 ${ }^{\circ} \mathrm{C}$ and $100 \mathrm{rpm}$ for 2 days. The culture was then transferred to the enzyme production medium which was consisted of $2 \%$ starch, $2 \%$ peptone, $0.2 \%$ yeast extract, $0.2 \% \mathrm{~K}_{2} \mathrm{HPO}_{4}, 0.1 \% \mathrm{MgSO}_{4}$ and $0.05 \%$ glycerol. Incubation conditions were as described above.

Enzyme isolation and precipitation: At the end of the incubation period ( 3 days), the culture was filtered through Whatman no.1 filter paper and the filtrate was cooled to $0{ }^{\circ} \mathrm{C}$. The enzyme was precipitated from the filtrate by adding one volume of cold acetone $\left(-15^{\circ} \mathrm{C}\right)$ with gentle stirring. The precipitate was dissolved in Tris-acetate buffer $(0.1 \mathrm{M}, \mathrm{pH} 6)$ and lyophilized.

Determination of transglutaminase activity: The activity was measured by the colorimetric hydroxamate procedure with N-carbo-benzoxy-L-glycine as the substrate according to the method of Folk (1970). Reaction mixture containing $50 \mu 1$ of the enzyme, $350 \mu 1$ of Tris-acetate buffer $(0.1 \mathrm{M}, \mathrm{pH} 6), 25 \mu 1$ of $2 \mathrm{M}$ hydroxylamine and $75 \mu \mathrm{l}$ of $0.1 \mathrm{M} \mathrm{CBZ-L-GLN-GLY,} \mathrm{was} \mathrm{incubated} \mathrm{at} 37{ }^{\circ} \mathrm{C}$ for 10 minutes and then the reaction was stopped by adding $500 \mu \mathrm{l}$ of $15 \%$ trichloroacetic acid (TCA) containing $5 \% \mathrm{FeCl}_{3}$. The absorbance was measured at $525 \mathrm{~nm}$ using CECIL 3021 spectrophotometer. One unit of transglutaminase 
activity was defined as the amount of enzyme which causes the formation of one micromole of hydroxamic acid per min at $37^{\circ} \mathrm{C}$. A calibration curve was prepared using L-glutamic acid $\gamma$-monohydroxamate.

Soft cheese manufacturing: Whole fresh cow milk (containing 3.7\% fat, $3.38 \%$ protein and $12.44 \%$ total solids) was pasteurized at $72{ }^{\circ} \mathrm{C}$ for 15 seconds, cooled down to $35{ }^{\circ} \mathrm{C}$ then calcium chloride $(0.3 \mathrm{gm} / 10 \mathrm{~kg})$ and the rennet were added followed by incubation for 40-45 minutes for coagulation then the curd was cut and left for 5 minutes. The separated whey was drained out and the salt was added ( $3 \%$ of curd weight) with mixing for five minutes. The curd was then transferred into plastic molds and pressed $\left(2 \mathrm{~kg} / \mathrm{cm}^{2}\right)$ for two hours. The produced cheese was then stored at $4{ }^{\circ} \mathrm{C}$.

Treatment with MTGase: The enzyme with concentrations ranging from 12-72 unit/liter milk was incorporated into the cheese at three different stages of manufacturing. In the first treatment, MTGase was added to the milk and incubated at $35{ }^{\circ} \mathrm{C}$ for 30 minutes before adding the rennet. In the second treatment, the enzyme was added with the rennet at the same time. In the third treatment, the enzyme was added after coagulation and curd cutting using the same concentrations. Chemical analysis of milk and cheese: Fat content of milk was estimated using Gerber method according to British Standards Institution (1969). Milk protein was estimated by Micro Kjeldahl method according to AOAC (2000). Total solids were measured by a hydrometer (Quevenne). $\mathrm{pH}$ of cheese was measured using a $\mathrm{pH}$ meter (WTW-530). Titratable acidity was estimated according to AOAC (2000). To detect the formation of cross-links, SDS-PAG electrophoresis was conducted for cheese and whey proteins by using vertical electrophoresis apparatus (Jookoh Co. LTD) following the procedure described by Laemmli (1970).

Determination of curd tension and cheese hardness: A texture analyzer with TA7 plate-shaped probe was used for curd tension measurement while a TA16 conical-shape probe was used for the measurement of cheese hardness. The force required to penetrate $20 \mathrm{~mm}$ of the sample at a speed of $1 \mathrm{~mm} . \mathrm{sec}^{-1}$ was estimated.

Sensory evaluation: Sensory evaluation of the produced cheese was carried out for flavor, texture, holes, consistency, color and bitterness after 1, 4, and 8 days of storage.

Statistical analysis: The data were analyzed by using the Complete Random Design (CRD). Sensory evaluation data were analyzed by using Factorial Complete Random Design (FCRD) according to SAS (2001).

\section{RESULTS AND DISCUSSION}

Soft cheese was manufactured using TGase-treated and untreated milks. Three treatments of the enzyme addition with various concentrations were tested.

Addition of MTGase prior or with the rennet addition: The addition of the enzyme to the milk prior to rennet addition caused the prevention of milk coagulation. The second treatment included the addition of MTGase to the milk with the rennet at the same time. This treatment caused a significant drop in the curd and cheese strength accompanied by a noticeable loss of protein and fat in the whey with all concentrations of the added enzyme (Table 1). The curd strength is considered as an important parameter in the cheese manufacture process due to its 
direct effect on cheese properties. Weak curd always produces cheese with low quality and yield due to the loss of noticeable amounts of protein and fat in the whey.

Table (1): Effect of the addition of various concentrations of Stv. Mobaraense TGase with the rennet on some of curd and cheese properties.

\begin{tabular}{|c|c|c|c|c|}
\hline $\begin{array}{c}\text { TGase conc. } \\
(\mathrm{U} / 1 \text { milk })\end{array}$ & $\begin{array}{c}\text { Curd strength } \\
\left(\mathrm{gm} / \mathrm{cm}^{2}\right)\end{array}$ & $\begin{array}{c}\text { Cheese strength } \\
\left(\mathrm{gm} / \mathrm{cm}^{2}\right)\end{array}$ & $\begin{array}{c}\text { Whey protein } \\
(\%)\end{array}$ & $\begin{array}{c}\text { Whey fat } \\
(\%)\end{array}$ \\
\hline 0 & 23.00 & 80.66 & 0.62 & 0.37 \\
\hline 12 & 17.66 & 77.00 & 0.67 & 0.41 \\
\hline 24 & 13.00 & 69.00 & 0.82 & 0.64 \\
\hline 36 & 10.00 & 42.66 & 0.95 & 0.70 \\
\hline 48 & 8.33 & 32.00 & 1.15 & 0.78 \\
\hline 60 & 7.33 & \multicolumn{3}{|c|}{ Weak curd, difficult to cut } \\
\hline 72 & 6.33 & \multicolumn{3}{|c|}{ Very weak curd, unable to cut } \\
\hline
\end{tabular}

The inhibitory effect of MTGase against coagulation process may be attributed to the formation of cross-links among casein molecules stimulated by MTGase which leads to the prevention of their hydrolysis by the clotting enzyme as a first step in casein coagulation. It was estimated that the ability of casein micelles to aggregate is mainly dependent on the hydrolysis degree of the surface $\kappa$-casein. Casein aggregation will not occur until about $88 \%$ of the $\kappa$-casein molecules have been hydrolyzed (Green and Morant, 1981). Casein is considered as a good substrate for MTGase action due to its open tertiary structure ( Christensen et al, 1996; Faeremand and Qvist, 1997). However, Tolkach and Kulozik (2005) mentioned the high availability of $\kappa$-casein to the MTGase action because it possesses four active glutamine residues, two of which are present in the hydrophilic caseinomacropeptide (CMP) region which are susceptible to cross-linking.

Addition of MTGase after coagulation and curd cutting step: The third trial was carried out by adding the MTGase after coagulation and curd cutting. This treatment was undertaken in order to avoid the inhibitory effect of MTGase against clotting enzyme activity. The same concentrations of the enzyme were used (12-72 U/liter). Results showed a significant drop in whey protein content and improvement in cheese hardness as a function of the added MTGase concentration. This indicated the formation of cross-links between whey proteins and curd proteins and the formation of a strong protein network (Table 2). In spite of the continuous decrease in protein percentage of the whey with increasing MTGase concentration up to 72 unit/l milk, maximum product hardness (240.66 gm) was achieved with 60 units/l and was significantly dropped (212.00 gm) upon increasing the enzyme concentration to 72 unit/l. This may be due to the effect of MTGase which was concentrated on the surfaces of the curd pieces producing hard individual pieces leading to the difficulty in pressing them into a homogenous piece and producing cheese with low texture.

The concomitantly increase of cottage cheese hardness with concentration increasing of the added TGase was reported by Cozzolino et al. (2003) and Han et al. (2003) who found that the texture of cottage cheese was improved upon MTGase treatment. 
Table (2): Effect of the addition of various concentrations of Stv. Mobaraense TGase after coagulation and curd cutting on whey protein percentage and cheese hardness.

\begin{tabular}{|c|c|c|c|c|c|c|c|}
\hline \multirow{2}{*}{ Properties } & \multicolumn{7}{|c|}{ Concentration of added MTGase (unit/1 milk) } \\
\cline { 2 - 8 } & 0 & 12 & 24 & 36 & 48 & 60 & 72 \\
\hline $\begin{array}{c}\text { Protein in } \\
\text { whey (\%) }\end{array}$ & $0.63^{\mathrm{a}}$ & $0.60^{\mathrm{b}}$ & $0.56^{\mathrm{c}}$ & $0.34^{\mathrm{d}}$ & $0.32^{\mathrm{de}}$ & $0.30^{\mathrm{ef}}$ & $0.29^{\mathrm{f}}$ \\
\hline $\begin{array}{c}\text { Cheese } \\
\text { hardness (gm) }\end{array}$ & $76.33^{\mathrm{g}}$ & $85.66^{\mathrm{f}}$ & $191.33^{\mathrm{e}}$ & $215.66^{\mathrm{c}}$ & $236.00^{\mathrm{b}}$ & $240.66^{\mathrm{a}}$ & $212.00^{\mathrm{d}}$ \\
\hline
\end{tabular}

Means in a row followed by similar letters represent non-significant differences $(\mathrm{p}<0.01)$.

The microstructure of treated cheese indicated that the curd contains small particles which causes the minimizing of the interspaces volume and leading to improve the product texture. The same result was obtained by the same authors upon the incorporation of MTGase in the milk used for manufacturing cream cheese in which the treatment had caused a significant increase in hardness and viscosity of the product.

Effect of MTGase treatment on cheese composition and yield: The best concentration of added MTGase for achieving maximum cheese hardness was found to be 60 unit/l milk. So, this concentration was used for producing soft cheese which

Table (3): Composition of soft cheese treated with Stv. Mobaraense TGase after coagulation and curd cutting.

\begin{tabular}{|l|c|c|}
\hline \multicolumn{1}{|c|}{$\begin{array}{c}\text { Components } \\
(\%)\end{array}$} & Untreated cheese & $\begin{array}{c}\text { MTGase treated cheese } \\
(60 \text { unit/1 milk })\end{array}$ \\
\hline Water & $60.09^{\mathrm{a}}$ & $59.50^{\mathrm{a}}$ \\
\hline Protein & $15.47^{\mathrm{b}}$ & $16.31^{\mathrm{a}}$ \\
\hline Fat & $18.61^{\mathrm{a}}$ & $19.23^{\mathrm{a}}$ \\
\hline Total solids & $39.90^{\mathrm{a}}$ & $40.50^{\mathrm{a}}$ \\
\hline Acidity (as lactic acid) & $0.172^{\mathrm{a}}$ & $0.170^{\mathrm{a}}$ \\
\hline pH & $6.50^{\mathrm{a}}$ & $6.57^{\mathrm{a}}$ \\
\hline Yield & $16.02^{\mathrm{b}}$ & $17.38^{\mathrm{a}}$ \\
\hline Protein in whey & $0.65^{\mathrm{a}}$ & $0.36^{\mathrm{b}}$ \\
\hline Fat in whey & $0.30^{\mathrm{a}}$ & $0.33^{\mathrm{a}}$ \\
\hline
\end{tabular}

Means in a row followed by similar letters represent non-significant differences $(p<0.01)$.

was compared with the untreated cheese (control). As shown in the Table (3), treating with MTGase caused a significant $(\mathrm{P}<0.01)$ increase in total protein content of the produced cheese accompanied by a significant decrease in whey protein content. Concerning the yield of the product, it was found that treatment with MTGase had significantly increased the cheese yield (17.38\%) as compared to the control sample (16.01\%). The MTGase-treated cheese was also characterized by a non-significant increase in total solids and fat. This may be due to the decrease of water content and to the increase of protein content. A non-significant increase in cheese $\mathrm{pH}$ accompanied by a small drop in the titratable acidity was also observed in the treated cheese. The results were in agreement with those of Han and Spradin (2000) who found that the treatment with MTGase had enhanced the 
efficiency of protein retaining and improving the yield of cottage cheese with saving all sensory attributes of the product.

SDS-PAGE profile of proteins in cheese and whey: The SDS electrophoresis profile was carried out for cheese of one-day age. Obvious differences between the MTGase-treated and the untreated samples. Two dense bands belonging to $\beta$-casein and $\alpha_{\mathrm{s}}$-casein were detected in the untreated cheese sample while in the MTGasetreated sample, a new high-molecular weight protein band was occurred accompanied with a high decrease in the $\beta$-casein band density and a slight decrease in the $\alpha_{\mathrm{s}}$-casein band density indicating that $\beta$-casein has a higher ability than $\alpha_{\mathrm{s}}$ casein to cross-linking (Fig. 1, A). The same observation was stated by Kuraishi et al. (2001), Huppertz and De kruif (2007) and Hinz et al. (2007) who stated that $\alpha_{\mathrm{s}^{-}}$ casein in MTGase-treated milk has lower ability to cross-link than $\beta$-casein. The
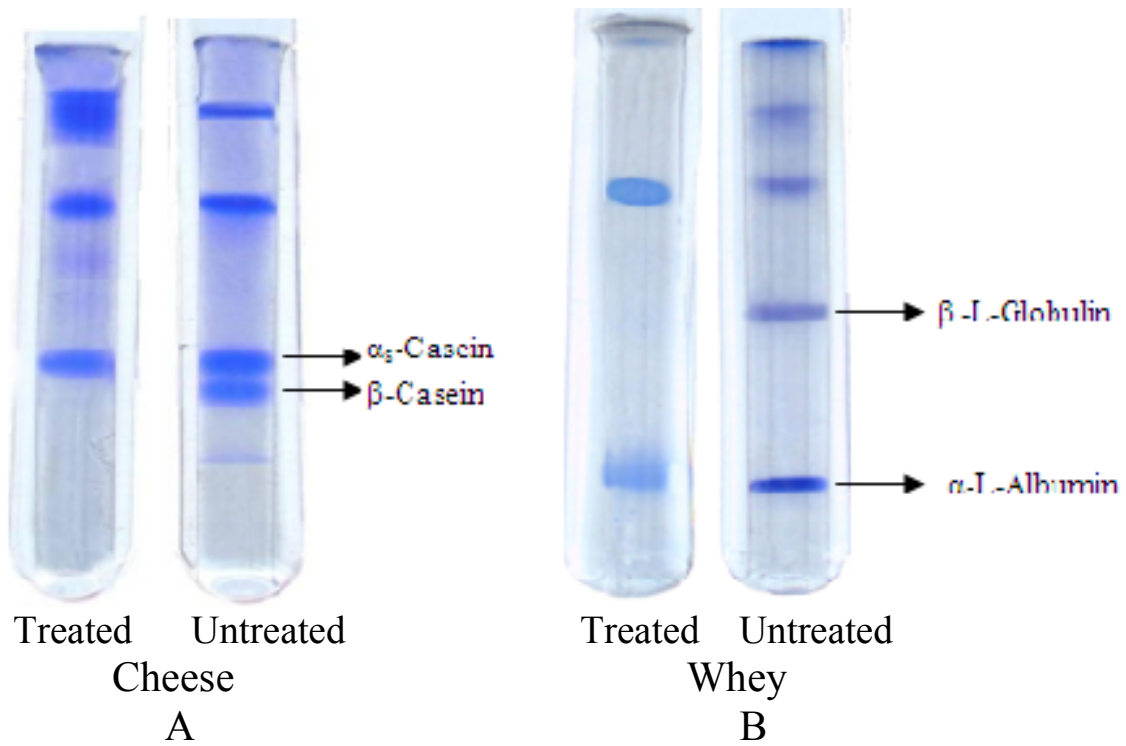

Fig. (1): SDS-PAGE profile of proteins in cheese and whey treated with MTGase.

electrophoretic profile of the treated whey proteins indicated the disappearance of $\beta$-lactoglobulin band and the decrease of $\alpha$-lactoalbumin density upon MTGase treatment (Fig. 1, B). These changes in electrophoretic profiles of cheese and whey proteins upon MTGase-treatment which were accompanied by the progressive decrease in whey protein content and conversely, the parallel increase in cheese protein content emphasize the cross-linking of these proteins with each others.

Sensory evaluation of MTGase-treated soft cheese: Sensory evaluation explains the product acceptability by the consumer. Table (4) shows the effect of MTGase treatment on some of sensory properties of soft cheese as a function of storage period compared with the untreated cheese (control). Results showed that the MTGase-treated of one-day age sample was superior to all other treatments in the overall evaluation. Concerning the untreated sample, it was noticed that the storage of cheese had caused retardation in almost all sensory attributes, some of which were significant $(p<0.01)$. This could be due to the effect of the deteriorative activities of microorganisms present in the cheese. However, no significant drop was observed in any of the properties of the MTGase-treated sample at the end of 
storage period. This may reveal that treating with MTGase had led to the elongation of cheese shelf life through the formation of cross-links which reduce the bioavailability of some necessary nutrients for the growth of deteriorative microorganisms. Han et al. (2003) noticed retardation of lactic acid bacteria growth and low acid formation upon the treatment of cream cheese with MTGase.

Table (4): Sensory evaluation of stored soft cheese treated with MTGase (60 units/l milk).

\begin{tabular}{|l|c|c|c|c|c|c|c|c|}
\hline Treatment & $\begin{array}{c}\text { Storage } \\
\text { time } \\
(\text { day })\end{array}$ & $\begin{array}{c}\text { Color } \\
(10)\end{array}$ & $\begin{array}{c}\text { Flavor } \\
(10)\end{array}$ & $\begin{array}{c}\text { Texture } \\
(10)\end{array}$ & $\begin{array}{c}\text { Consistency } \\
(10)\end{array}$ & $\begin{array}{c}\text { Holes } \\
(10)\end{array}$ & $\begin{array}{c}\text { Bitterness } \\
(10)\end{array}$ & $\begin{array}{c}\text { Total } \\
\text { Scores } \\
(60)\end{array}$ \\
\hline \multirow{3}{*}{ Control } & 1 & $9.71^{\mathrm{a}}$ & $8.92^{\mathrm{a}}$ & $8.50^{\mathrm{a}}$ & $8.35^{\mathrm{abc}}$ & $8.78^{\mathrm{abc}}$ & $9.85^{\mathrm{a}}$ & $54.14^{\mathrm{ab}}$ \\
\cline { 2 - 9 } & 4 & $9.57^{\mathrm{a}}$ & $9.57^{\mathrm{a}}$ & $8.35^{\mathrm{a}}$ & $8.57^{\mathrm{bc}}$ & $8.57^{\mathrm{bcd}}$ & $9.85^{\mathrm{a}}$ & $54.50^{\mathrm{bc}}$ \\
\cline { 2 - 9 } & 8 & $9.50^{\mathrm{a}}$ & $7.94^{\mathrm{b}}$ & $8.50^{\mathrm{a}}$ & $8.24^{\mathrm{c}}$ & $8.47^{\mathrm{d}}$ & $9.65^{\mathrm{a}}$ & $52.31^{\mathrm{d}}$ \\
\hline $\begin{array}{l}\text { MTGase } \\
\text { Treated } \\
(60 \mathrm{U} / 1)\end{array}$ & 1 & $9.71^{\mathrm{a}}$ & $9.28^{\mathrm{a}}$ & $9.64^{\mathrm{a}}$ & $9.64^{\mathrm{a}}$ & $9.35^{\mathrm{a}}$ & $10.00^{\mathrm{a}}$ & $57.64^{\mathrm{a}}$ \\
\cline { 2 - 9 } & 4 & $10.00^{\mathrm{a}}$ & $9.71^{\mathrm{a}}$ & $9.14^{\mathrm{a}}$ & $9.35^{\mathrm{ab}}$ & $8.85^{\mathrm{ab}}$ & $10.00^{\mathrm{a}}$ & $57.07^{\mathrm{a}}$ \\
\hline
\end{tabular}

Means in a column followed by similar letters represent non-significant differences $(\mathrm{p}<0.01)$.

One of the important properties of the MTGase-treated cheese which had noticed by the panel test was the absence of separated whey during storage. On the contrary, syneresis was occurred in the untreated cheese sample. This high waterholding capacity was due to the formation of a protein network which enclosed water and other components. The other observation was the rich creamy taste and improved mouth feel of the product as compared with the control sample. The same observation was stated by Zhu (1997). However, several articles had mentioned the ability of improving the sensory properties of proteinous dairy product by the incorporation of transglutaminase enzyme ( Kuraishi et al., 1997; Motoki and Seguro, 1998; Lorenzen and Schlimme, 1998; Jaros et al., 2006).

$$
\begin{aligned}
& \text { تأثير المعاملة بإنزيم الترانس كلوتامينيز الميكروبي في صفات الجبن الطري }
\end{aligned}
$$

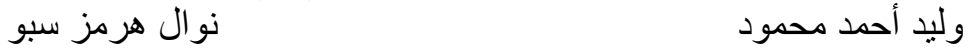

$$
\begin{aligned}
& \text { كلية الزر اعة و الغابات/ جامعة الموصل/العراق اق كلية الزر اعة/جامعة صلاح الدين/العر اق }
\end{aligned}
$$

\section{الخلاصة}

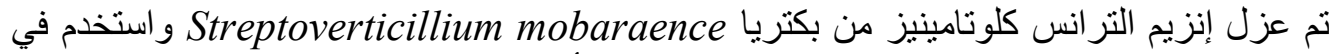

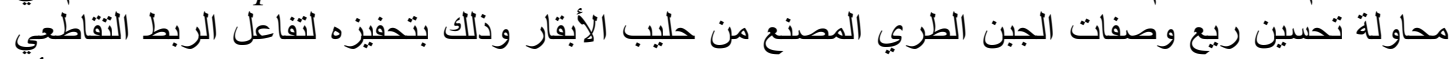

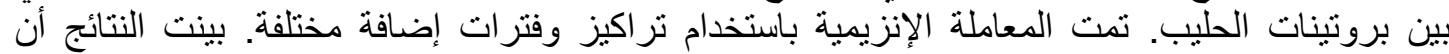

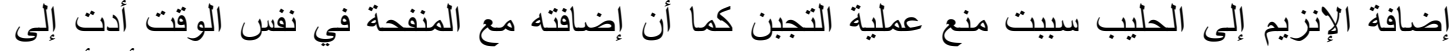

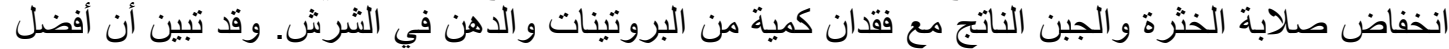

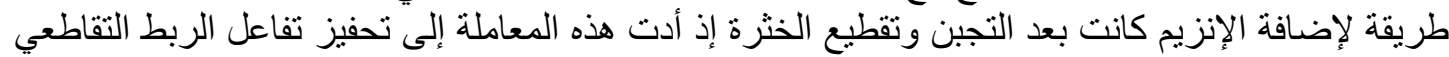

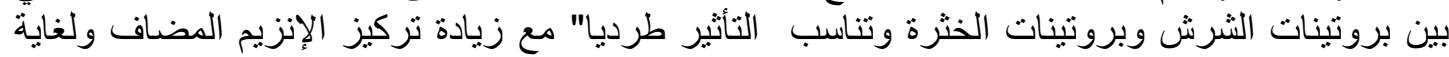

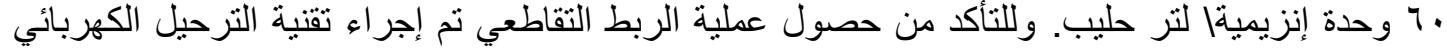

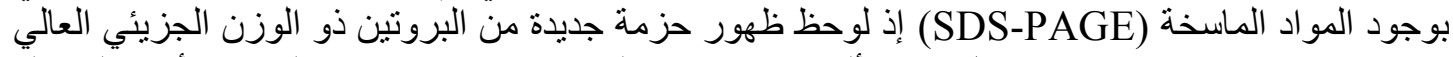

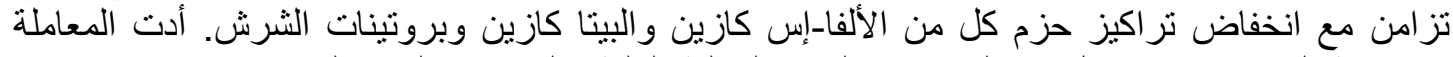
الإنزيمية إلى زيادة نسب كل من البروتين و المواد الصلبة الكلية والريع في الجبن النين الناتج مع انخفاض تركيز 


\section{البروتين في الثرش المفصول. أظهر التقويم الحسي للجبن المعامل بالإنزيم تفوقا" على الجبن غير المعامل وخلال فترة الخزن البالغة ثمانية أيام.}

\section{REFERENCES}

AOAC (Association of Official Analytical Chemists), (2000). Official Methods of Analysis, $17^{\text {th }}$ ed., Washington.

Ando, H., M. Adachi, K. Umeda, A. Matsuura, M. Nonaka, R. Uchio, H. Tanaka and M. Motoki (1989). Purification and characterisation of a novel transglutaminase derived from microorganisms. Agric. Biol. Chem., V. 53, No. 10: 2613-2617.

British Standard Institution (1969). Gerber method of determination of fat in milk Product. Part 2, B.S. 696.

Christensen, B. M., E. S. Sorensen, P. Hojrup, T. E. Petersen and L. K. Rasmussen (1996). Localization of potential transglutaminase cross-linking sites in bovine caseins. J. Agric. Food Chem., V. 44, No. 7, pp. 1943-1947.

Cozzoline, A., P. Di Pierro, L. Mariniello, A. Sorrentino, P. Masi and R. Porta (2003). Incorporation of whey proteins into cheese curd by using transglutaminase. Biotechnol. Appl. Biochem. J., V. 38, pp. 289-295.

Ernstrom, C. A., B. J. Sutherland and G. W. Jameson (1980). Cheese base for processing a high yield product from whole milk by ultrafiltration. J. Dairy Sci., V. 63 No.2, pp. 228-234.

Fargemand, M. and K. B. Qvist (1997). Transglutaminase: Effect on rheological properties, micro structure and permeability of set style acid skim milk gel. Food Hydrocolloids, V. 11 No. 3, pp. 287-292.

Folk, J. K. (1970). Tranglutaminase, in: Methods in Enzymology, (ed.), H. Tabor and C.W. Tabor, V. 17, pp. 889-894. Academic Press, New York.

Green, M. L. and S. V. Morant (1981). Mechanism of aggregation of casein micelles in rennet - treated milk. J. dairy Res., V. 48, pp. 57-63.

Han, X. Q. and J.E. Spradin (2000). process for making cheese using transglutaminase and a non-rennet protease. Eur. Patent No. 1057411A2.

Han, X. Q., J.K. Pfeifer, R.H. Lincourt and J.M. Schuerman (2003). Process for making a cheese product using transglutaminase. US Patent No. 0054069A1.

Hinrichs, J. (2001). Incorporation of whey proteins in cheese. Int. Dairy J., V. 11, pp. 495-503.

Hinz, K., T. Huppertz, U. Kulozik and A. L. Kelly (2007). Influence of enzymatic cross-linking on milk fat globules and emulsifying properties of milk proteins. Int. Dairy J., V. 17, No. 4, pp. 289-293.

Huppertz, T. and C. G. De Kruif (2007). Rennet induced coagulation of enzymatically cross linked casein micelles. Int. Dairy J., V. 17, No. 5, pp. 442447.

Jaros, D., C. Partschefeld, T. Henle and H. Rohm (2006). Transglutaminase in dairy products: Chemistry, Physics, Applications. J. of Texture Studies, V. 37, pp. 113-155.

Kosikowski, F. V. (1977). Cheese and fermented milk foods. 2nd ed. Edwards Brothers Inc., Michigan, USA. 
Kuraishi, C., J. Sakamoto and T. Soeda (1997). Process for producing cheese using transglutaminase. US Patent No. 5681598.

Kuraishi, C., K. Yamazaki and Y. Susa (2001). Transglutaminase: its utilization in food industry. Food Rev. Int. V. 17, No. 2, pp. 221-246.

Laemmli, U. K. (1970). Cleavage of structural protein during the assembly of head of bacteriophage T4. Nature, V. 227, pp. 680-685.

Lo, C. G. and E. D. Bastian (1998). Incorporation of native and denatured whey proteins into cheese curd for manufacture of reduced fat Havarti-type cheese. J. Dairy Sci., V. 81, No. 1, pp. 16-24.

Lorenzen, P. C. and E. Schlimme (1998). Properties and potential fields of application of transglutaminase preparations in dairying. Bull IDF, V. 332, pp. 47-53.

Motoki, M., and K. Seguro (1998). Transglutaminase and its use for food processing. Trends Food Sci. Technol., V. 9, pp. 204-210.

O' Reilly, C. E., A. L. Kelly, P. M. Murphy and T. P. Beresford (2001). High pressure treatment: Applications in cheese manufacture and ripening. Trends in Food Sci. Technol., V. 12, No. 2, pp.51-59.

SAS (2001). Guide for Personal Computer. Release 6.18, Cary, NC, SAS Inst. Inc., USA.

Seguro, K., N. Nio and M. Motoki (1996). Some characteristics of a microbial protein cross-linking enzyme: Transglutaminase. in: Macro Molecular Interactions in Food Technol., edited by Parris, N; A. Kato; L. K. Creamer; J. Pearce, ACS Symposium Series 650, American Chemical Society Columbus, OH. pp. 271-280.

Tolkach, A. and U. Kulozik (2005). Fractionation of whey proteins and caseinomacropeptide by means of enzymatic cross linking and membrane separation techniques. J. Food Engineering, V. 67, pp. 13-20.

Zhu, Y. (1997). Process development for microbial transglutaminase production. WAU dissertation No. 2350.

Zhu, Y., A. Rinzema, J. Tramper and J. Bol (1995). Microbial transglutaminase - a review of its production and application in food processing. Appl. Microbiol. Biotechnol., V. 44, No. 3-4, pp. 277-282. 